\section{Incidence of End Rots and Internal Necrosis in Sweetpotato Is Affected by Cultivar, Curing, and Ethephon Defoliation}

\author{
Christopher A. Clark ${ }^{1,6}$, Washington L. da Silva ${ }^{1}$, \\ Ramón A. Arancibia ${ }^{2}$, Jeff L. Main ${ }^{2}$, Jonathan R. Schultheis ${ }^{3}$, \\ Zvezdana Pesic van-Esbroeck ${ }^{4}$, Chen Jiang $^{3}$, and Joy Smith ${ }^{5}$
}

\begin{abstract}
ADDITIONAL INDEX WORDs. ethylene, Ipomoea batatas, postharvest storage
SUMMARY. Two distinct syndromes have emerged in some production areas that have caused losses of sweetpotato (Ipomoea batatas) storage roots during postharvest storage: a complex of fungal rots (end rots) progressing from either end of storage roots and a necrotic reaction (internal necrosis) progressing internally from the proximal end of storage roots. This study was conducted in multiple environments to evaluate whether the use of preharvest ethephon application and storage with or without curing after harvest could be used to screen sweetpotato breeding lines for susceptibility/resistance to these two disorders. Treating vines with ethephon 2 weeks before harvest and placing harvested roots directly into storage at $60{ }^{\circ} \mathrm{F}$ without curing resulted in the greatest incidence of end rots in each state and there were significant differences in incidence among the sweetpotato genotypes evaluated. However, when ethephon was not used and roots were cured immediately after harvest, the incidence of end rots was low in all the genotypes evaluated except for one breeding line. Incidence and severity of internal necrosis were greatest when ethephon was applied preharvest and roots were cured immediately after harvest, but two cultivars, Hatteras and Covington, had significantly more internal necrosis than all others.
\end{abstract}

$\mathrm{P}$ roduction and consumption of sweetpotatoes has steadily increased in recent years as recognition of their benefits to a healthy diet and availability of more diverse

This work was funded by the USDA-NIFA Specialty Crop Research Initiative grant number 2009-5118106071, the Louisiana Sweet Potato Commission, the Mississippi Sweet Potato Council, and the North Carolina Sweet Potato Commission.

The authors acknowledge the assistance of Lori Grelen, Mary W. Hoy, Rebecca R. Sweany, Brad Thompson, and Xiang Wang.

Mention of a trademark, proprietary product, method, or vendor does not imply endorsement by Louisiana State University Agricultural Center, Mississippi State University, or North Carolina State University and does not imply its approval to the exclusion of other products or vendors that also may be suitable.

${ }^{1}$ Department of Plant Pathology \& Crop Physiology, 302 Life Science Building, Louisiana State University Agricultural Center, 110 Union Square Station, Baton Rouge, LA 70803

${ }^{2}$ Pontotoc Ridge-Flatwoods Branch Experiment Station, North Mississippi Research and Extension Center, Mississippi State University, 8320 Hwy 15 South, Pontotoc, MS 38863

${ }^{3}$ Department of Horticultural Science, North Carolina State University, Box 7609, 2721 Founders Drive, Raleigh, NC 27695

${ }^{4}$ Department of Plant Pathology, North Carolina State University, 3709 Hillsborough Street, Raleigh, NC 27695

${ }^{5}$ Statistics Department, North Carolina State University, Box 8203, 2311 Stinson Drive, Raleigh, NC 27695

${ }^{6}$ Corresponding author. E-mail: cclark@agcenter.lsu.edu. products has increased (U.S. Department of Agriculture, 2011). The need to continually supply both fresh and processing markets has increased simultaneously, resulting in increased need to store sweetpotatoes for up to 1 year. Given the high cost of both production and storage of sweetpotatoes, it is essential for producers to pack out as great a proportion of the stored sweetpotatoes as possible. Sweetpotatoes are routinely cured immediately after harvest by holding them for 4 to $7 \mathrm{~d}$ at $85^{\circ} \mathrm{F}$ and $90 \%$ relative humidity (RH) to promote healing of wounds incurred during harvest, thus reducing microbial infection and water loss during storage (Clark et al., 2013a). In addition, recent research suggests that chemical defoliation before harvest may increase skin adherence and reduce skinning during harvest and subsequent handling (Schultheis et al., 2000; Wang et al., 2013).
In the past 5 to 10 years, two problems have emerged in some locations that have seriously reduced pack-out efficiency: end rots and internal necrosis. The end rot complex includes aggressive rots progressing from either the proximal or the distal end of the root or both and a more restricted tip rot that appears in storage near the proximal end of the root (Arancibia et al., 2013; Clark et al., 2013a). Various fungi have been isolated from each type of lesion from affected roots including species of Fusarium that are not recognized as plant pathogens, as well as recognized sweetpotato pathogens including Fusarium solani, Macrophomina phaseolina, Lasiodiplodia theobromae, and Diaporthe batatatis (da Silva and Clark, 2012; Stokes et al., 2012). These fungi have also been isolated frequently from symptomless transplants and storage roots and it appears that infection is not a limiting factor to the development of this disease complex (da Silva, 2013). Internal necrosis appears as brown to black discolored areas that develop during storage near the proximal end of storage roots and the symptoms are predominantly internal and not apparent unless the root flesh is cut to expose the internal tissue. Since no microorganisms are consistently associated with internal necrosis, it is believed to be a physiological disorder (Jiang, 2013; Schultheis et al., 2009).

From recent studies and anecdotal observations from growers, two factors have been suggested to increase the incidence of both end rots and internal necrosis. Flooding in the field shortly before harvest has been suggested to increase both problems as has use of ethephon when used to kill vines before harvest (Arancibia et al., 2013; Dittmar et al., 2010). Cultivars may also vary in susceptibility to both disorders, but this hypothesis has not been investigated. This study was undertaken to determine the susceptibility of major sweetpotato cultivars and advanced breeding lines to the end rot complex and internal necrosis

\begin{tabular}{llll}
\hline $\begin{array}{l}\text { Units } \\
\text { To convert U.S. to SI, } \\
\text { multiply by }\end{array}$ & U.S. unit & SI unit & $\begin{array}{l}\text { To convert SI to U.S., } \\
\text { multiply by }\end{array}$ \\
\hline 2.54 & inch $(\mathrm{es})$ & $\mathrm{cm}$ & 0.3937 \\
1.1692 & $\mathrm{pt} / \mathrm{acre}$ & $\mathrm{L} \cdot \mathrm{ha}^{-1}$ & 0.8553 \\
$\left({ }^{\circ} \mathrm{F}-32\right) \div 1.8$ & ${ }^{\circ} \mathrm{F}$ & ${ }^{\circ} \mathrm{C}$ & $\left({ }^{\circ} \mathrm{C} \times 1.8\right)+32$
\end{tabular}




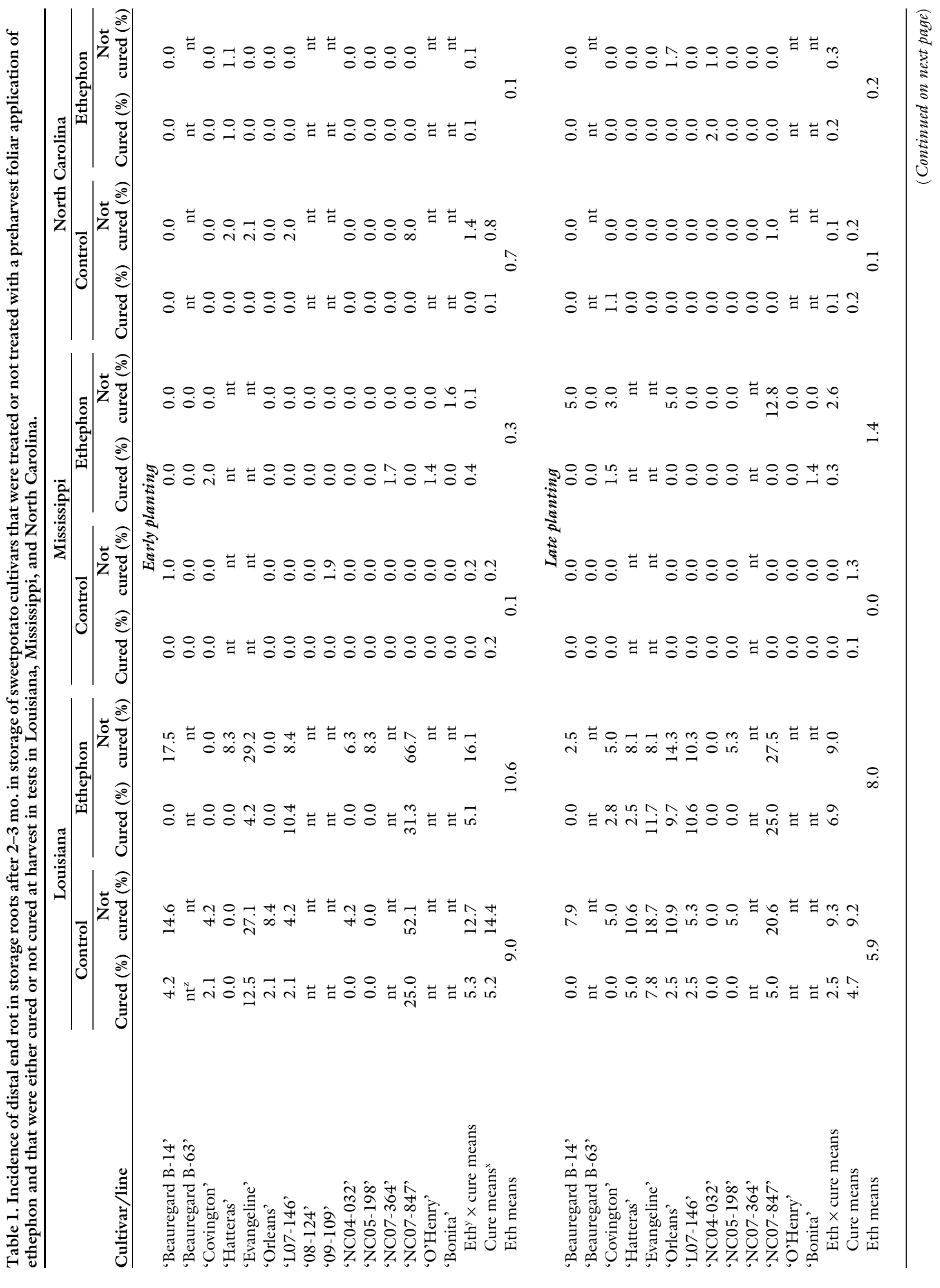




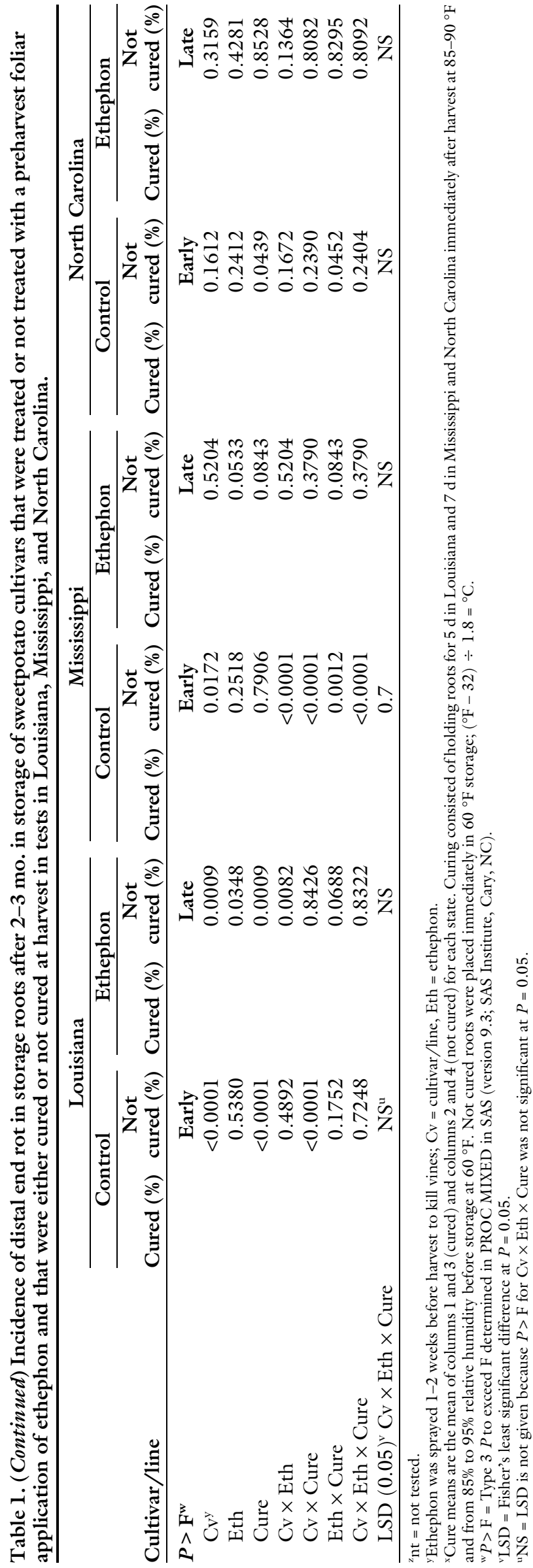

with or without the use of ethephon as a vine killer before harvest, and also to determine the effect of curing on incidence and severity of both disorders. The primary goal of the study was to determine if sweetpotato breeders could use ethephon treatment and curing manipulations as screening tools for new genotypes for their susceptibility to the end rot complex and/or internal necrosis.

\section{Materials and methods}

Experiments were conducted in the field at the Louisiana State University Agricultural Center, Burden Center in Baton Rouge, LA, at the Pontotoc Ridge-Flatwoods Experiment Station in Pontotoc, MS, and the Horticultural Crops Research Station in Clinton, NC, during the 2012 growing season. Two tests were conducted at each location: one planted early and one planted late in the planting season. In Louisiana, the early planting was transplanted on 18 May and harvested on 6 Sept. (112 d) and the late planting was transplanted on 26 June and harvested on 22 Oct. (118 d). In Mississippi, the early planting was transplanted on 7 June and harvested on 4 Oct. (119 d) and the late planting was transplanted on 26 June and harvested on 22 Oct. (118 d). In North Carolina, the early planting was transplanted on 29 May and harvested on 28 Sept. (122 d) and the late planting was transplanted on 19 June and harvested on 19 Oct. (122 d). Plots were transplanted with transplants that were 10 to 12 inches long and cut above the soil from plant beds. Rows were 42 to 48 inches apart and transplants were set 12 inches apart within each row. Commercial cultivars currently used in the United States and experimental lines from the breeding programs at Louisiana State University Agricultural Center and North Carolina State University were used in this study. At each of the three states (Louisiana, Mississippi, and North Carolina) and two planting times (early and late), the study was set up as a strip block design. There were four blocks (replications) in each study. The cultivars were randomly assigned to plots within each block and 20 plants were planted in each plot. Each block was divided into two horizontal strips with a buffer between the strips and the ethephon spray was applied to one of the two horizontal strips. This 


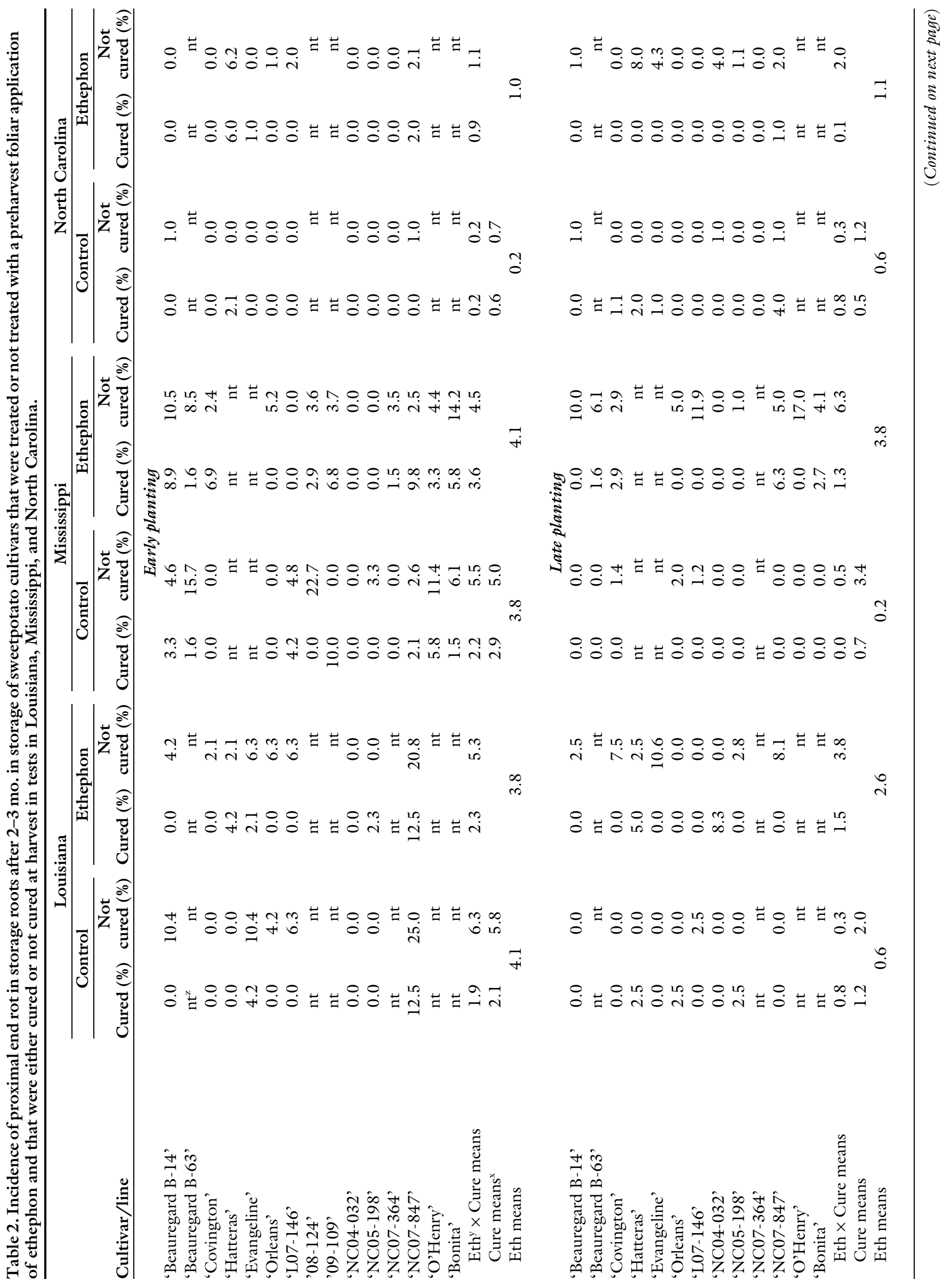




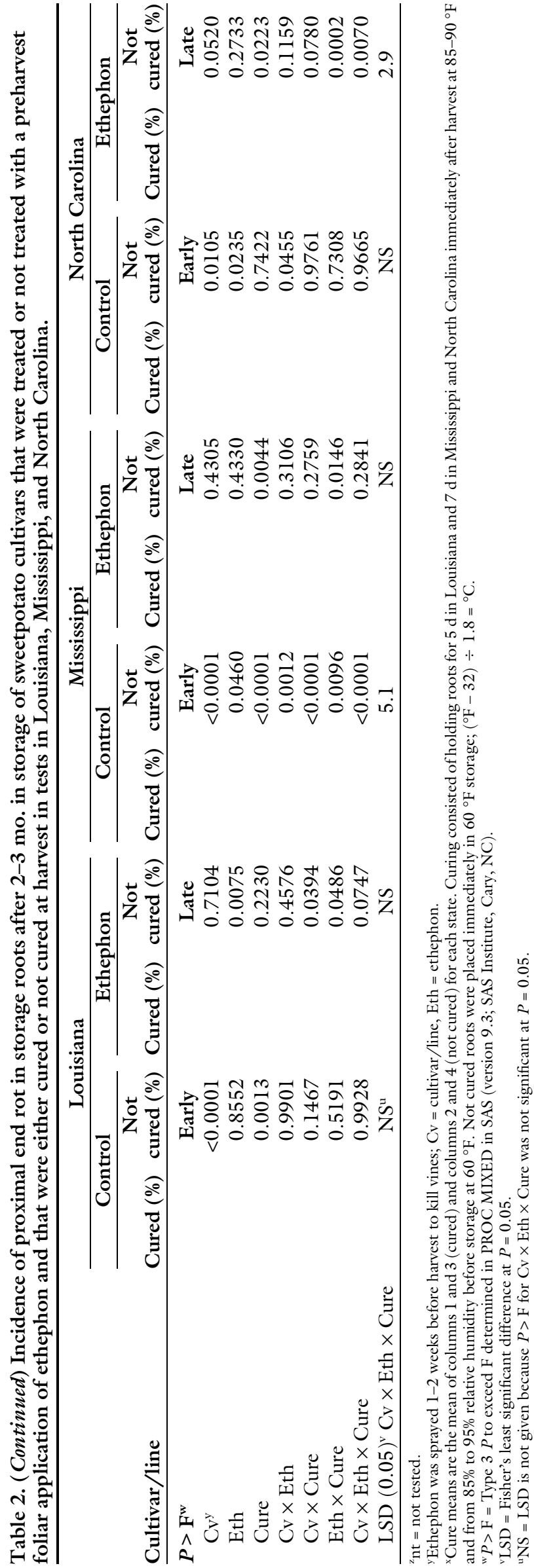

design was used to prevent drift of the ethephon onto untreated subplots. Ethephon-treated subplots were sprayed with ethephon at $1.3 \mathrm{pt} /$ acre 2 weeks before harvest in Louisiana and North Carolina, and at $1.1 \mathrm{pt} /$ acre 1 week before harvest in Mississippi. Ethephon was applied as Prep (Bayer CropScience, Research Triangle Park, NC) in Mississippi and North Carolina, and Boll Buster (Loveland Products, Greeley, CO) in Louisiana (both are $55.4 \%$ ethephon and $44.6 \%$ inert). At harvest, two lots (sub-subplots) of 10 to 20 U.S. no.l size roots (from $1-3 / 4$ to $3-1 / 2$ inches diameter, 3 to 9 inches long) were randomly collected from each subplot and placed in nylon mesh or paper bags. One lot from each subplot was cured at 85 to $90{ }^{\circ} \mathrm{F}$ and from $85 \%$ to $90 \% \mathrm{RH}$ for $5 \mathrm{~d}$ in Louisiana and $7 \mathrm{~d}$ in Mississippi and North Carolina before being placed in storage at $60{ }^{\circ} \mathrm{F}$ while the other lot was placed immediately in storage at $60^{\circ} \mathrm{F}$ without curing. The roots were stored for 2 to 3 months because internal necrosis expression is typically maximized by $60 \mathrm{~d}$ after harvest (Dittmar et al., 2010). After roots were removed from storage and washed, the incidence of roots with proximal end rot (a dry rot progressing symmetrically from the proximal end of the root and affecting the entire cross section of the root), distal end rot (a dry rot progressing symmetrically from the distal end of the root and affecting the entire cross section of the root), tip rot (occurs at or near the proximal end of the root, develops asymmetrically, is usually restricted and shallow but sometimes extends into the interior of the root), and other rots were recorded. The roots without extensive end rots were then cut from the proximal end to at least the middle of the root into slices $\approx 3 / 16$ inch thick and the incidence of internal necrosis was recorded. Severity of internal necrosis was also recorded using a scale of 0 to 4 where $0=$ no internal necrosis, $\mathrm{l}=\mathrm{a}$ single spot less than $3 / 16$ inch diameter near the proximal end of the root, $2=$ darkened area $\approx 3 / 16$ to $1 / 2$ inch diameter near the proximal end of the root, $3=$ diffuse area $>1 / 2$ inch diameter of necrosis near the proximal end of the root, and $4=$ severe discoloration extending at least onethird of the length of the root. 


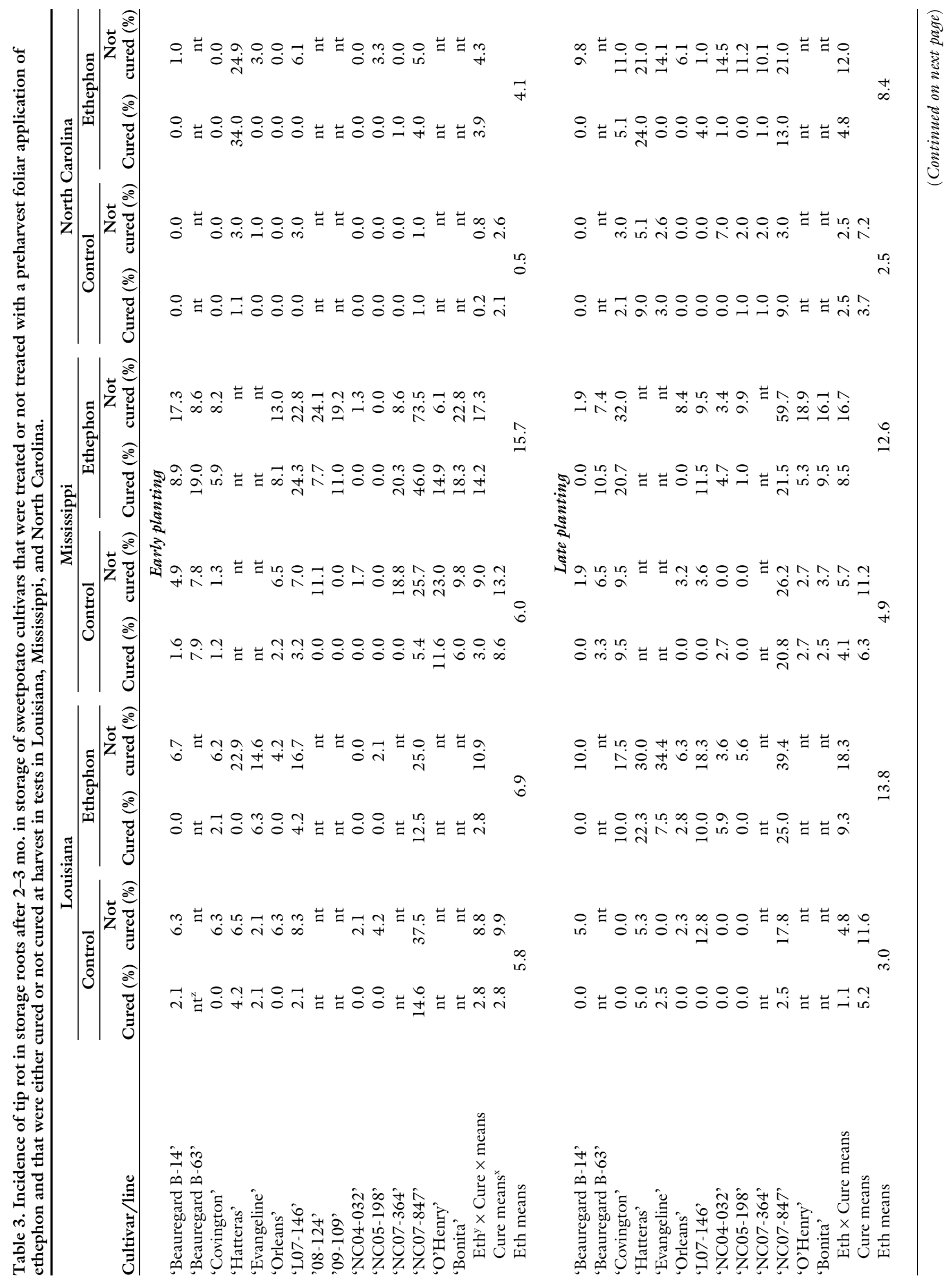

Hortlechnology · December 2013 23(6) 


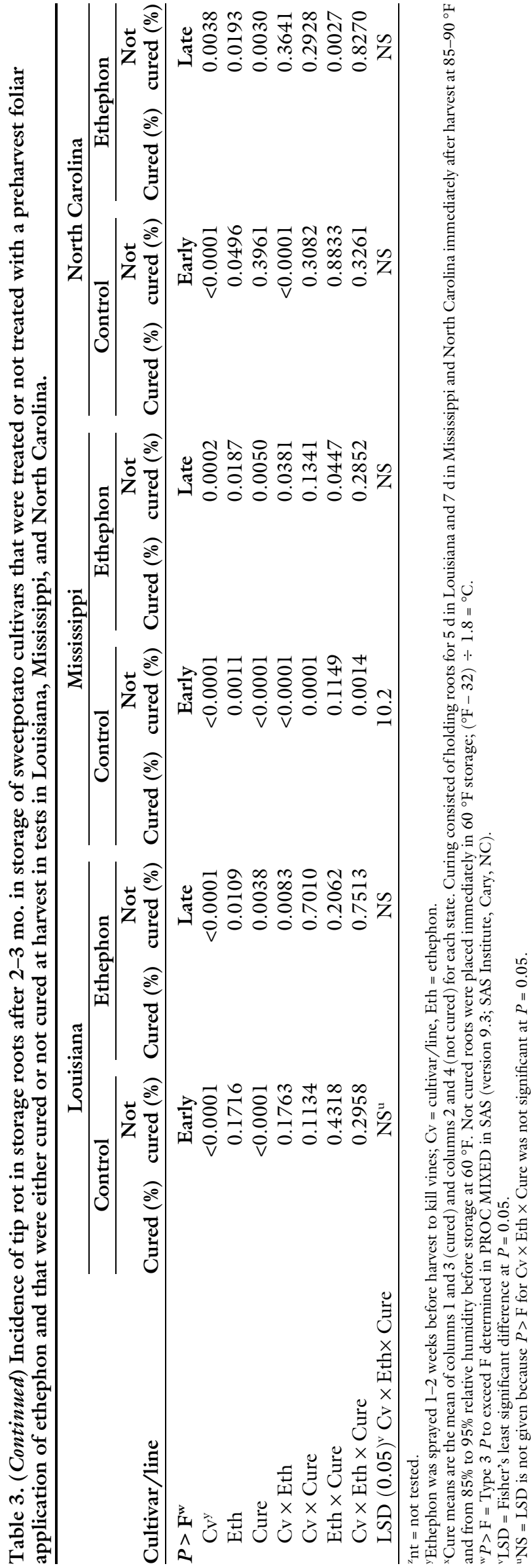

Incidence of end rots and internal necrosis was recorded as the percentage of the 10 to 20 randomly collected roots from each subplot with symptoms. Both arcsin-transformed data and nontransformed percentage data were analyzed using PROC MIXED in SAS (version 9.3; SAS Institute, Cary, NC). Each planting date in each state was analyzed separately. Arcsin transformation equalized the variance slightly in some cases. Results from analyses of untransformed percentage data are reported because the arcsin transformation did not improve the analysis in general and there was concern that the arcsin transform might increase the risk of type 1 error due to the high frequency of $0 \%$ incidence of disease. Conclusions from these analyses should be interpreted with caution due to the high frequency of $0 \%$ incidence of symptoms and thus some violation of assumptions for analysis of variance.

\section{Results and discussion}

Depending on state and planting date, significant differences in incidence of distal end rot, proximal end rot, and tip rot were observed among cultivars, ethephon treatments before harvest, and curing after harvest with some significant two- and three-way interactions. Distal end rot was common in Louisiana, especially in the early planting that was exposed to flood stress shortly before harvest (Table 1). Distal end rot was minimal in Mississippi and North Carolina and appeared mainly in a few cultivars in the late planting treated with ethephon and not cured (Table 1). Significant differences in distal end rot incidence among cultivars and curing treatments were only observed in Louisiana. Ethephon increased distal end rot in the late Louisiana planting. 'Evangeline' and 'NC07-847' had the highest incidence of distal end rot in Louisiana.

Differences in proximal end rot incidence were evident among cultivars in the early harvest in all three states (Table 2). Ethephon increased proximal end rot in late harvest in Louisiana and the early harvests in Mississippi and North Carolina. Curing reduced the incidence of proximal end rot in the early harvests in Louisiana and Mississippi, and late harvests in Mississippi and North Carolina. 'Evangeline' and 'NC07-847' in Louisiana, 'Beauregard B-14', 'Beauregard B-63', 


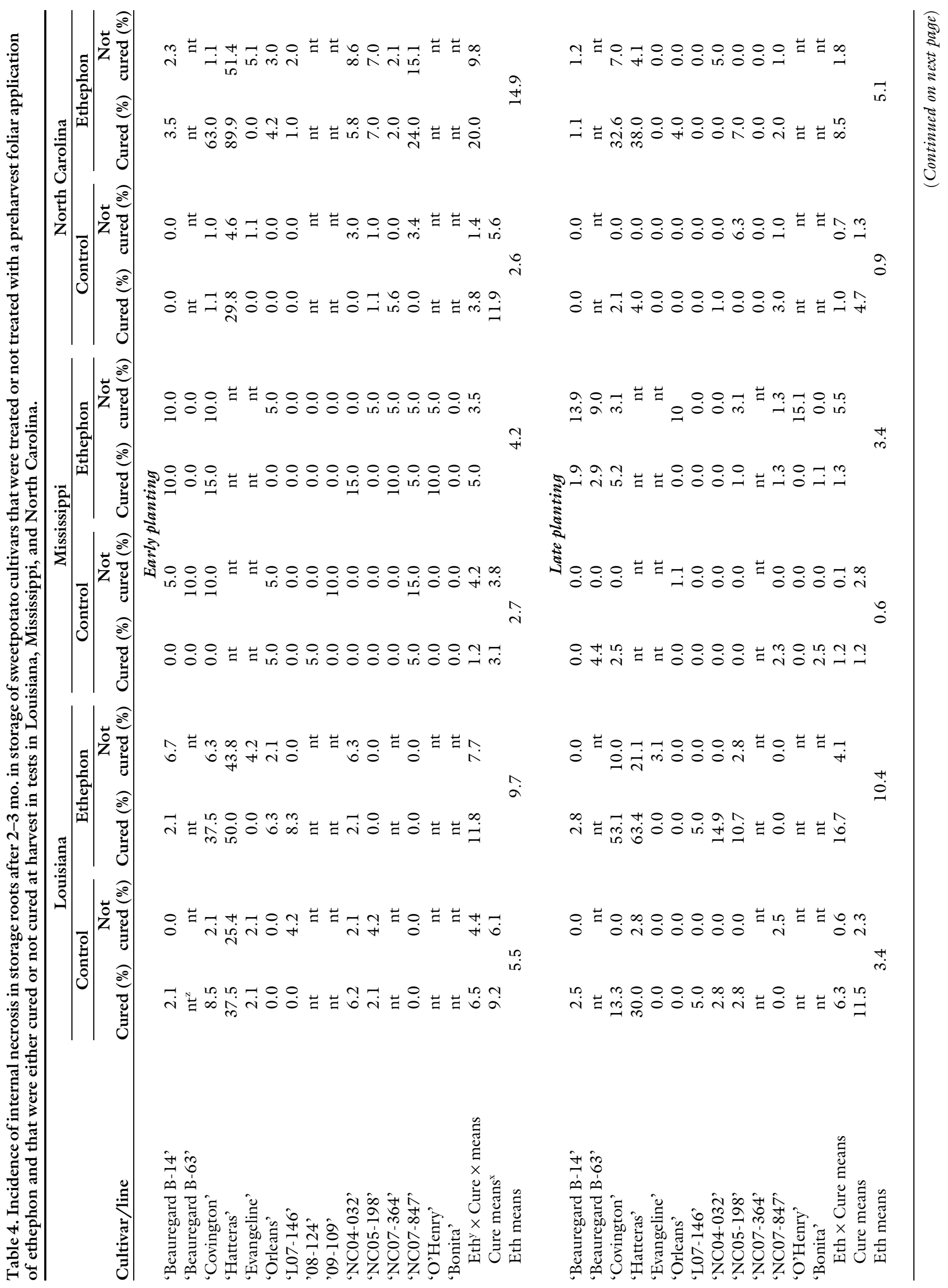




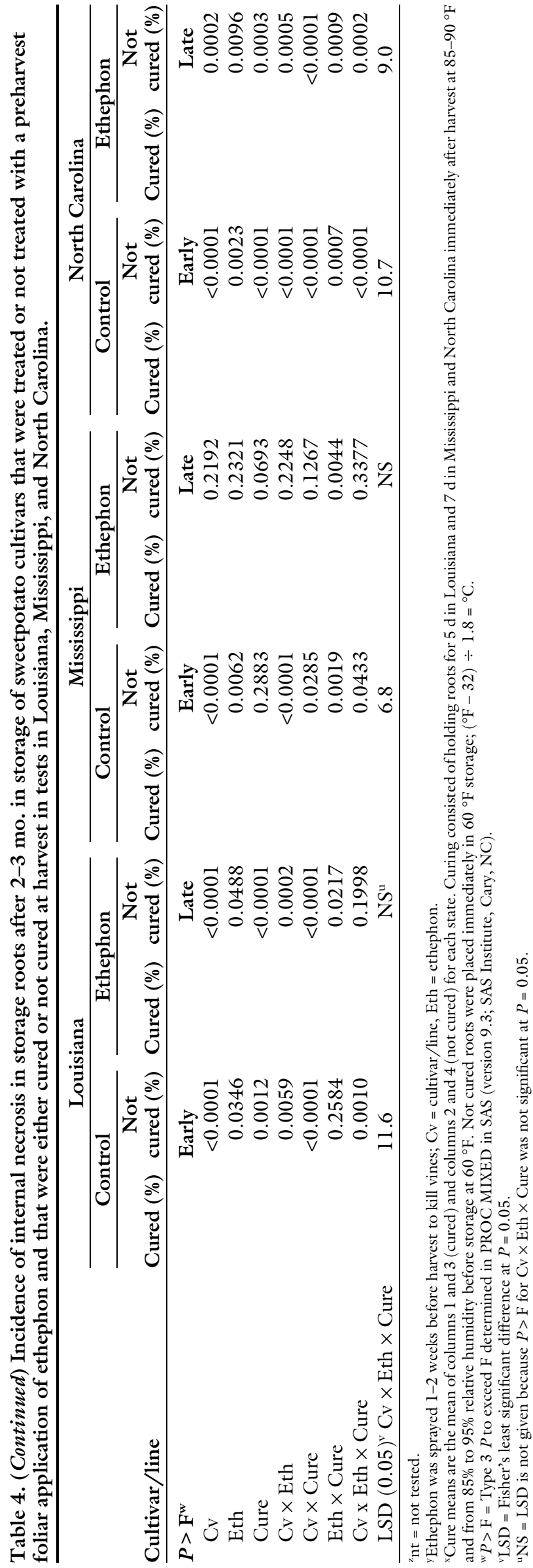

'08-124', 'Bonita', and 'O'Henry' in Mississippi, and 'Hatteras' in North Carolina were among the most susceptible cultivars to proximal end rot, particularly when they were not cured.

Tip rot incidence was influenced by all three factors (cultivar, ethephon, and curing) in all states and both harvests with the exception of ethephon in the early harvest in Louisiana and curing for the early harvest in North Carolina (Table 3). In general, preharvest foliar application of ethephon increased tip rot incidence while curing reduced it. Cultivars that performed consistently better in all three states with/without ethephon application were 'Orleans', 'NC04-032', and 'NC05-198'. Cultivars that were most susceptible especially with ethephon application were 'NC07-847', 'Hatteras', and 'Evangeline'. Although ethephon increased the incidence of tip rot in most cultivars, 'NC07-847' was particularly susceptible with and without ethephon application.

Overall, trends were similar for cumulative end rots (all end rots = distal end rot, proximal end rot, and tip rot) in Louisiana, Mississippi, and North Carolina. The lowest incidence of all end rots occurred when no ethephon treatment was applied before harvest and the roots were cured. Under these conditions, most of the genotypes evaluated had less than $10 \%$ incidence. Curing has been previously reported as an option to reduce the incidence of end rots (Arancibia et al., 2013; Clark et al., 2013a). In Louisiana, 'Evangeline' had $\approx 20 \%$ and 'NC07-847' had $\approx 50 \%$ of all end rots. The greatest incidence of all end rots occurred when ethephon was used and roots were not cured. Under these conditions, most roots of ' $\mathrm{NC07-}$ 847 ' developed one or more end rots in Louisiana and Mississippi, but the incidence remained comparatively low for all genotypes in North Carolina. Tip rot was the prevalent end rot in Mississippi and North Carolina while distal end rot was much more common in Louisiana (Tables 1-3).

'Hatteras' had consistently greater incidence of internal necrosis regardless of other treatments, except for those not treated with ethephon and not cured at the late planting (Table 4). 'Hatteras' is not available for commercial production because of this problem. 'Hatteras' and 'Covington' also had greater severity of internal necrosis 
Table 5. Severity of internal necrosis in storage roots after 2-3 mo. in storage of sweetpotato cultivars that were treated or not treated with a preharvest foliar application of ethephon and that were either cured or not cured at harvest in tests in Louisiana, Mississippi, and North Carolina.

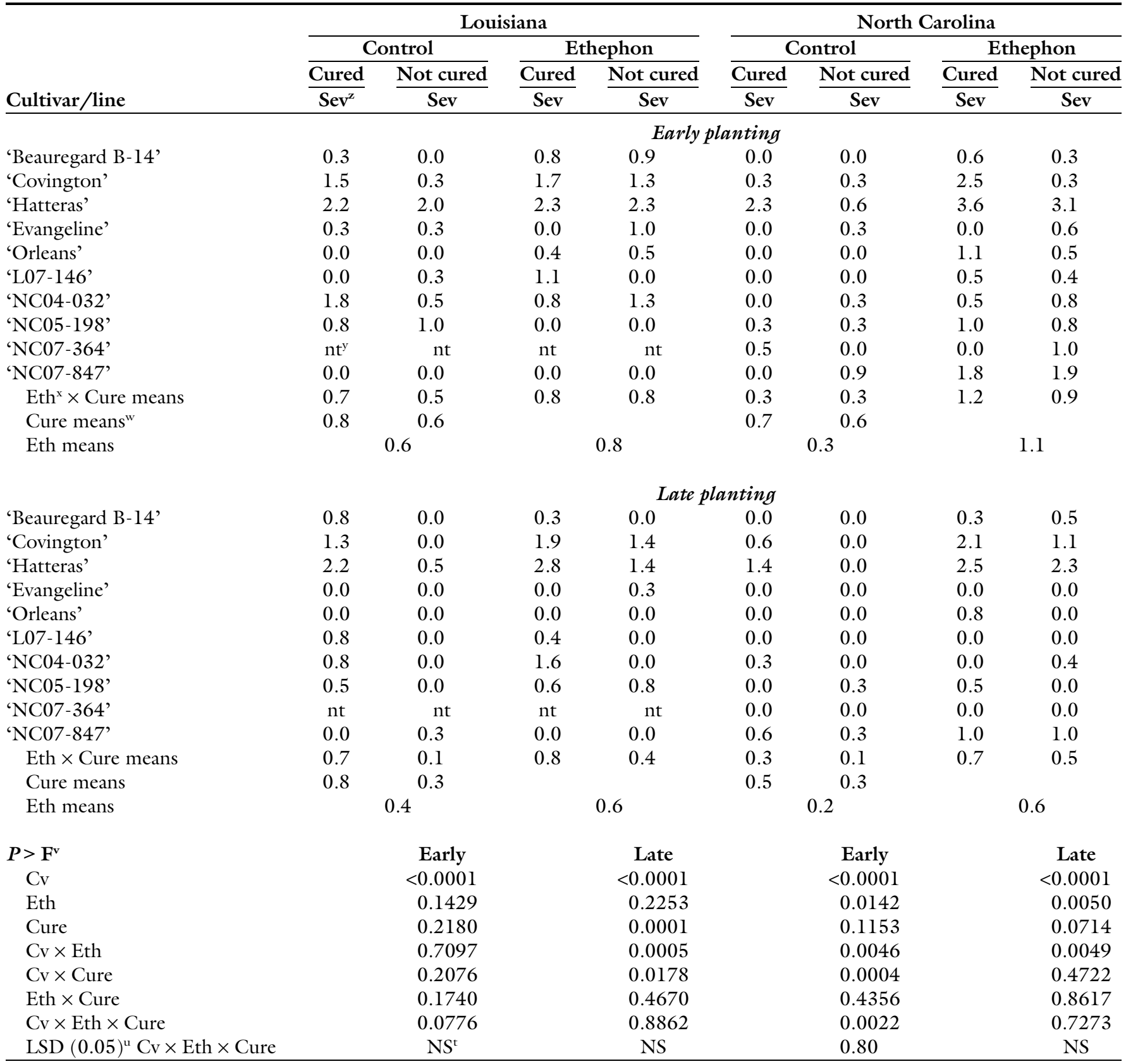

${ }^{\mathrm{z}} \mathrm{Sev}=$ severity index on a scale of $0=$ no internal necrosis to $4=$ most severe.

${ }^{y}$ nt $=$ not tested.

${ }^{x}$ Ethephon was sprayed $1-2$ weeks before harvest to kill vines; $\mathrm{Cv}=$ cultivar/line, Eth $=$ ethephon.

"Cure means are the mean of columns 1 and 3 (cured) and columns 2 and 4 (not cured) for each state. Curing consisted of holding roots for $5 \mathrm{~d}$ in Louisiana and $7 \mathrm{~d}$ in Mississippi and North Carolina immediately after harvest at $85-90^{\circ} \mathrm{F}$ and from $85 \%$ to $95 \%$ relative humidity before storage at $60{ }^{\circ} \mathrm{F}$. Not cured roots were placed immediately in $60{ }^{\circ} \mathrm{F}$ storage; $\left({ }^{\circ} \mathrm{F}-32\right) \div 1.8={ }^{\circ} \mathrm{C}$.

${ }^{v} P>F=$ Type $3 P$ to exceed F determined in PROC MIXED in SAS (version 9.3; SAS Institute, Cary, NC).

"LSD = Fisher's least significant difference at $P=0.05$.

${ }^{\mathrm{t}} \mathrm{NS}=\mathrm{LSD}$ is not given because $P>\mathrm{F}$ for $\mathrm{Cv} \times$ Eth $\times$ Cure was not significant at $P=0.05$.

with means ranging generally 1.3 and above (on a scale of $0-4$ ) while the other genotypes consistently had the minimal $(<1)$ or 0 severity score (Table 5 ). Little internal necrosis was observed in Mississippi, but the most susceptible cultivar, 'Hatteras', was not included in the Mississippi tests. Exposure to ethephon consistently increased the incidence but not the severity of internal necrosis (Tables 4 and 5 ). Curing also increased the incidence (Table 4) and in one test the severity (Table 5) of internal necrosis. This agrees with Jiang (2013) who found that curing enhances the occurrence and severity of internal necrosis in 'Covington'. The incidence of internal necrosis was minimal when ethephon was not used in the commercial cultivars that are currently grown on significant acreage: 'Covington', 'Beauregard', 'Evangeline', 'Orleans', and 'L07-146'. Avoiding the application of ethephon before 
harvest has been recommended to reduce the occurrence of internal necrosis (Dittmar et al., 2010), although other factors may contribute to internal necrosis. Although internal necrosis incidence was low in 'Covington' when it was not treated with ethephon and roots were not cured, it had a high incidence and severity when ethephon was used and roots were cured, and moderate levels in some other cases. Incidence and severity of internal necrosis was generally low for the advanced breeding lines with the exception of ' $\mathrm{NC07}$ 847', which had moderate incidence in ethephon-treated plots in Mississippi and North Carolina (Table 4).

The role of curing in end rot and internal necrosis development deserves further study. Curing is known to promote wound healing of harvested sweetpotato storage roots. This results in reduced water loss from the roots during storage and can also prevent infection by pathogens that enter the roots through wounds (Clark et al., 2013a). However, recent research indicates that many of the pathogenic fungi isolated from sweetpotatoes with end rots can also be isolated from apparently healthy plants and storage roots (da Silva and Clark, 2012; Stokes et al., 2012). Given the significant reductions in end rots from curing, consideration should be given to the possibility that curing may affect disease development in additional ways above and beyond wound healing. It is not known why curing increases internal necrosis, but given the critical importance of curing to multiple aspects of sweetpotato storage, managing internal necrosis by not curing is not a viable option. Therefore, efforts to manage internal necrosis should emphasize the use of resistant/tolerant cultivars and cultural practices that minimize ethylene exposure.

These results confirm earlier reports that ethephon treatment increases the incidence of tip rot (Arancibia et al., 2013) and internal necrosis (Dittmar et al., 2010). Although exposure of sweetpotatoes to ethephon increases the incidence of both end rots and internal necrosis, it is not yet clear whether it has a direct causal role in these disorders or is merely a predisposing factor. It is known that as with many other plants, sweetpotatoes produce ethylene in response to wounding (Randle and Woodson,
1986). Sweetpotato cultivars differ in the amount of ethylene they produce (Saltveit and Locy, 1982) and in their sensitivity to the effects of ethylene (Villordon et al., 2012). Although ethylene can promote lignification and wound healing during curing (St. Amand and Randle, 1989), preliminary studies suggest that ethylene induced by flooding promotes lenticel proliferation (Clark et al., 2013b), which in turn may provide openings for invasion by bacterial soft rot pathogens and/or potentially increase water loss from roots during storage. More research is needed to better understand the interactions of ethylene with sweetpotato and the practical consequences of these interactions. Although application of ethephon is an obvious source of exposure to ethylene, there may be other sources of ethylene exposure that have not yet been characterized. Flooding in the field may stimulate ethylene production by sweetpotato plants (Paterson et al., 1979). The early planting in Louisiana in this study had $\approx 15$ inches of rain in the 3 weeks before harvest and also had greater incidence of end rots and internal necrosis in the plots not treated with ethephon than in any of the other harvests. However, Dittmar et al. (2010) did not find an effect of high moisture stress before harvest on internal necrosis. The role of flooding and other stresses in inducing ethylene production needs further characterization.

Although growers in some locations have experienced serious losses to end rots in 'Beauregard' sweetpotatoes, our data suggests that 'Beauregard' and most other sweetpotato cultivars can be grown and stored with minimal losses to end rots. Proper curing immediately after harvest has been recommended for decades (Clark et al., 2013a) and remains a critically important management practice for storing sweetpotatoes as shown in this study by the significant reductions in end rots. Minimizing unnecessary exposure of sweetpotatoes to ethylene, such as by mechanically devining the crop before harvest rather than using ethephon can also significantly reduce end rot occurrence (Arancibia et al., 2013). In part, because of this study, 'NC07-847' will not be released as a commercial cultivar due to its higher incidences of end rot and internal necrosis (G.C. Yencho, personal communication). Finally, treating advanced sweetpotato lines with ethephon from 1 to 2 weeks before harvest and storing roots with and without curing appears to have utility for enabling breeders to identify and eliminate breeding lines that are especially susceptible to end rots or internal necrosis.

\section{Literature cited}

Arancibia, R.A., J.L. Main, and C.A. Clark. 2013. Sweetpotato tip rot incidence is increased by preharvest applications of ethephon and reduced by curing. HortTechnology 23:288-293.

Clark, C.A., D.M. Ferrin, T.P. Smith, and G.J. Holmes (eds.). 2013a. Compendium of sweetpotato diseases, pests, and disorders. 2nd ed. APS Press, St. Paul, MN.

Clark, C.A., W. da Silva, and A. Villordon. 2013b. Lenticel proliferation and flooding associated soft rot in sweetpotato. HortScience (In press).

da Silva, W.L. 2013. Sweetpotato storage root rots: Flooding-associated bacterial soft rot caused by Clostridium spp. and infection by fungal end rot pathogens prior to harvest. La. State Univ., Baton Rouge, MS Thesis. <http://etd.lsu.edu/ docs/available/etd-04042013-111405/>.

da Silva, W.L. and C.A. Clark. 2012. Infection of sweetpotato by fungal end rot pathogens prior to harvest. Phytopathology 102:S2.2-S2.3. (Abstr.).

Dittmar, P.J., K.M. Jennings, D.W. Monks, and J.R. Schultheis. 2010. Determining the effect of ethylene on internal black marbling expression in sweetpotato. HortScience 45:488-489. (abstr.).

Jiang, C. 2013. Sweetpotato root quality in response to abiotic factors and maximizing greenhouse plant production by adjusting fertilizer application rates. N. Car. State Univ., Raleigh, MS Thesis. <http:// repository.lib.ncsu.edu/ir/handle/ 1840.16/8714>.

Paterson, D.R., D.R. Earhart, and M.C. Fuqua. 1979. Effects of flooding level on storage root formation, ethylene production, and growth of sweet potato. HortScience 14:739-740.

Randle, W.M. and W.R. Woodson. 1986. The effect of storage and wounding on ethylene production by sweet potato. HortScience 21:1018-1019.

Saltveit, M.E. and R.D. Locy. 1982. Cultivar differences in ethylene production by wounded sweet potato roots. J. Amer. Soc. Hort. Sci. 107:1114-1117. 
Schultheis, J.R., S.M. Blankenship, D.W. Monks, and M.D. Boyette. 2000. Preharvest methods to reduce skinning in 'Beauregard' sweetpotato. HortScience 35:444 (abstr.).

Schultheis, J.R., Z. Pesic-VanEsbroeck, K.M. Jennings, P.J. Dittmar, and A.C. Thornton. 2009. Effects of environmental stress and pathogens on the internal mottling and end rots of sweetpotato in new commercial varieties ('Hatteras' and 'Covington'), and established commercial varieties ('Beauregard' and 'Carolina Ruby'). North Carolina Res. Ext. Rpt. 2009. North Carolina State University, Raleigh, NC.
St. Amand, P.C. and W.M. Randle. 1989. Ethylene production and wound healing in sweet potato roots. HortScience 24: 805-807.

Stokes, C.E., S.W. Woolfolk, R.A. Arancibia, and R.E. Baird. 2012. Diversity, densities, and distribution of microbial communities in sweetpotato end/tip rot diseases. HortScience 47:S47-S48 (abstr.).

U.S. Department of Agriculture. 2011. U.S. Sweet Potato Statistics (03001). 3 May 2013. <http://usda.mannlib.cornell. edu/MannUsda/viewDocumentInfo.do? documentID $=1492>$.
Villordon, A., C. Clark, D. LaBonte, and N. Firon. 2012. 1-Methylcyclopropene has a variable effect on adventitious root emergence from cuttings of two sweetpotato cultivars. HortScience 47:17641767.

Wang, X., R.A. Arancibia, J.L. Main, M.W. Shankle, and D.R. LaBonte. 2013. Preharvest foliar applications of ethephon increases skin lignin/suberin content and resistance to skinning in sweetpotato storage roots. HortScience 48:1270-1274. 